\title{
PENGARUH METODE PEMBELAJARAN THINK TALK WRITE (TTW) TERHADAP KEMAMPUAN MENULIS PUISI MELALUI ALIRAN EKSPRESIONISME PADA SISWA KELAS X SMK TAMANSISWA KISARAN \\ TAHUN PELAJARAN 2016/2017
}

\author{
OLEH \\ TUTI HERAWATI \\ Dosen FKIP Universitas Asahan \\ tutiherawatiapri@gmail.com
}

\begin{abstract}
ABSTRAK
Penelitian ini merupakan penelitian eksperimen yaitu untuk melihat pengaruh metode Think Talk Write (TTW) terhadap kemampuan menulis puisi melalui Aliran ekspresionisme. Tujuan penelitian ini untuk mengetahui apakah ada pengaruh atau tidak ada pengaruh metode Think Talk Write (TTW) terhadap kemampuan menulis puisi aliran ekspresionisme di kelas X SMK Tamansiswa Kisaran. Populasi dalam penelitian ini adalah siswa kelas X SMK Tamansiswa Kisaran kelas $X$ AK-1 sebagai kelas eksperimen dan X MB-1sebagai kelas kontrol, masingmasing terdiri dari 36 siswa. Instrumen dalam penelitian ini berupa tes unjuk kerja menulis puisi aliran ekspresionisme. Setelah data dikumpul kemudian dianalisis. Pengujian persyaratan anlisis data meliputi uji normalitas data dengan menggunakan uji Lilliefors dan uji homogenitas data dengan menggunakan uji F. Pengujian hipotesis menggunakan uji t pada taraf signifikasi $5 \%=2,00$, dan taraf signifikasi $1 \%=2,65$. Berdasarkan hasil data post tes diperoleh rata- rata hasil belajar menulis puisi aliran ekspresionisme dengan menggunakan metode Think Talk Write adalah 48,10 dan tanpa menggunakan metode Think Talk Write (TTW) 45,75. Hasil perhitungan uji hipotesis diperoleh harga $t_{\text {hitung }}=3,74$, dengan melihat tabel nilai $t$ dengan taraf nyata $\alpha=0,05$ diperoleh $t_{\text {tabel }} 1,67$. Harga $t_{\text {hitung }}=3,74>t_{\text {tabel }} 1,67$ dapat disimpulakan bahwa hasil belajar siswa yang diajarkan dengan menggunakan Metode Think Talk Write lebih baik dari pada hasil belajar siswa yang diajarkan tanpa menggunakan metode Think Talk Write ( TTW).
\end{abstract}

Kata Kunci : Metode Pembelajaran Think Talk Write ( TTW ) dan Menulis Puisi Aliran Ekpresionisme.

\section{Pendahuluan}

Pendidikan sangat penting dalam kehidupan tidak dapat dipisahkan dari kehidupan manusia. Untuk itu, pendidikan harus dilaksanakan dengan sebaik-baiknya sehingga memperoleh hasil yang sesuai

ISSN 2541-3775 dengan yang diharapkan. Upaya yang dapat dilakukan adalah meningkatkan mutu pendidikan dan meningkatkan sistem pendidikan yang digunakan. " Strategi Pembelajaran Think Talk Write (TTW) dapat menumbuh kembangkan kemampuan 
pemecahan masalah.” Alur kemajuan pembelajaran Think Talk Write (TTW) dimulai dari keterlibatan siswa dalam berpikir atau berdialog dengan dirinya sendiri setelah proses membaca, selanjutnya berbicara dan membagi ide dengan temannya sebelum menulis. "Berdasarkan uraian latar belakang masalah di atas, maka penulis tertarik untuk melakukan penelitian dengan judul “ Pengaruh Model Pembelajaran Think Talk Write (TTW) terhadap kemampuan menulis puisi melalui Aliran ekpresionisme oleh siswa kelas X SMK Tamansiswa Kisaran Tahun Pelajaran 2016/2017.”

Kerangka Teoritis merupakan tempat peneliti melakukan menjelaskan tenteng hal-hal yang berhubungan dengan variabel pokok, sub variabel atau pokok masalah yang ada dalam penelitian” (Arikunto,2005:72). Teori-Teori tersebut digunakan sebagai bahan acuan untuk pembahasan selanjutnya. Teori-teori yang relevan. Waluyo (1991:25), menyatakan bahwa " Puisi adalah bentuk karya sastra yang mengungkapkan pikiran dan perasaan secara imajinatif dan disusun dengan mengkonsentrasikan semua kekuatan bahasa dengan pengkonsentrasian struktur fisik dan struktur batinnya ". ekspresionisme adalah aliran dalam kesusastraan yang merupakan pernyataan jiwa seseorang secara sepontan. Aliran ini diartikan sebagai aliran seni yang melukiskan perasaan dan penginderaan batin yang timbul dari pengalaman dan pada akhirnya aliran ini memunculkan ekspresi subyektivitas manusia, dan hak-haknya yang bebas dan berfikir sebagaimana yang disukai.

Siswa berinteraksi dan berkolaborasi dengan teman satu grup untuk membahas isi catatan dari hasil catatan (talk). Dalam kegiatan ini mereka menggunakan bahasa dan kata-kata mereka sendiri untuk menyampaikan ide-ide dalam diskusi. Pemahaman dibangun melalui interaksinya dalam diskusi. Diskusi diharapkan dapat menghasilkan solusi atas soal yang diberikan.

Hipotesis adalah jawaban sementara terhadap masalah penelitian yang perlu dikaji kebenarannya berdasarkan data penelitian. Arikunto (2002: 64) "Hipotesis adalah jawaban yang bersifat sementara terhadap permasalahan penelitian tanpa terbukti melalui data yang terkumpul”.

Berdasarkan kerangka teoretis dan konseptual maka hipotesis penelitian ini adalah Ha: Terdapat pengaruh yang signifikan antara kemampuan menulis puisi melalui aliran ekspresionisme dengan menggunakan metode pembelajaran Think Talk Write oleh siswa kelas X SMK Tamansiswa Kisaran Tahun Pelajaran 
2016/2017. Ho: Tidak terdapt pengaruh yang signifikan antara menulis puisi melalui aliran ekspresionisme dengan menggunakan metode pembelajaran Think Talk Write oleh siswa kelas X SMK Tamansiswa Kisaran Tahun Pelajaran 2016/2017.

Instrumen adalah suatu alat yang digunakan untuk mengukur atau menjaring data penelitian. Data merupakan informasi yang diperoleh dari setiap penelitian. Dalam penelitian ini instrumen yang digunakan untuk menjaring data adalah tes unjuk kerja siswa dalam menulis puisi. Kriteria penilaian menulis petunjuk meliputi : Kriteria penilaian menulis puisi meliputi: (1) diksi (pemilihan kata), (2) pengimajian, (3) kata konkret, (4) rima, (5) Bahasa Figuratif (Majas).

Tes ini akan diberlakukan untuk posttest. Menghitung Mean rata-rata variabel, Standar Deviasi, dan Standar Eror a.Mean rata-rata variabel 1 dengan rumus: $\mathrm{M}_{1}=\frac{\sum x}{N_{1}}$, Menghitung Standar Deviasi Variabel 1 dengan rumus

$$
\mathrm{SD}_{1}=\sqrt{\frac{\sum_{x} 2}{n}} \text {, Menghitung Standar Eror }
$$

variabel 1 dengan rumus $\mathrm{SE} \mathrm{M}_{1}=\frac{S D_{1}}{\sqrt{N-1}}$

Mean rata-rata variabel II dengan rumus:
$\mathrm{M}_{2}=\frac{\sum y}{N_{2}}$, Menghitung Standar Deviasi

Variabel II dengan rumusSD $2=\sqrt{\frac{\sum_{y} 2}{n}}$

Menghitung Standar Eror variabel 1 dengan rumus $\mathrm{SE}_{\mathrm{M} 2}=\frac{S D_{2}}{N_{2}-1}$, Mencari standar eror perbedaan mean variabel 1 dan variabel 11 dengan rumus: $\mathrm{SE}_{\mathrm{M} 1-\mathrm{M} 2}=\sqrt{\left(\mathrm{SE}_{M 1^{2}}\right)}+$ $\left(\mathrm{SE}_{M 2^{2}}\right)$

Tabel 4.2 Menacri Mean, Standard Deviasi Variabel I

\begin{tabular}{|l|l|l|l|l|l|}
\hline Skor & $\mathbf{F}$ & $\mathbf{F y}$ & $\mathbf{Y}$ & $\mathbf{Y}^{2}$ & $\mathbf{F Y}^{2}$ \\
\hline 35 & 6 & 210 & - & 167,96 & 671,8 \\
40 & 5 & 200 & 12,96 & 63,36 & 4 \\
45 & 8 & 520 & $-7,96$ & 8,76 & 253,4 \\
55 & 6 & 420 & $-2,96$ & 4,16 & 4 \\
60 & 5 & 375 & 2,04 & 49,56 & 70,08 \\
68 & 6 & 400 & 7,04 & 144,96 & 24,96 \\
& & & 12,04 & & 247,8 \\
& & & & & 724,8 \\
\hline & $\mathbf{3 6}$ & $\mathbf{1 7 5 4}$ & & & $\mathbf{1 9 9 2 ,}$ \\
& & & & & $\mathbf{9 2}$ \\
\hline
\end{tabular}

Keterangan:

$\mathrm{Y}=$ nilai postest

$\mathrm{N}=$ jumlah siswa keseluruhan

$\mathrm{F}=$ jumlah siswa pemerolehan nilai posttest. Uji Homogenitas yaitu untuk mengethui apakah mempunyai varians yang homogen atau tidak Kriteria 
pengujiannya $X_{2}$ hitung $<X_{2}$ tabel maka varians populasi adalah homogen.

\begin{tabular}{|l|l|l|l|l|l|}
\hline $\begin{array}{l}\text { Sa } \\
\text { mp } \\
\text { el }\end{array}$ & $\begin{array}{l}\mathrm{Db}= \\
\mathrm{N}-1\end{array}$ & $\begin{array}{l}1 / \mathrm{Db} \\
-\mathrm{N}_{1}\end{array}$ & $\mathrm{Si}^{2}$ & $\mathrm{Log} \mathrm{Si}^{2}$ & $\begin{array}{l}(\mathrm{db}) \\
\mathrm{Log} \\
\mathrm{Si}^{2}\end{array}$ \\
\hline $\mathrm{X}$ & 31 & 0,03 & 63,84 & 1,80 & 55,8 \\
\hline $\mathrm{Y}$ & 31 & 0,03 & 62,25 & 1,79 & 55,49 \\
\hline $\begin{array}{l}\text { Ju } \\
\text { mla } \\
\mathrm{h}\end{array}$ & 61 & & & & $\begin{array}{l}111,2 \\
9\end{array}$ \\
\hline
\end{tabular}

\section{Uji Hipotesis}

$$
\begin{aligned}
\mathrm{t}_{0} & =\frac{M 1-M 2}{\text { SE M1-SE M2 }} \\
& =\frac{86,87-67,96}{1,43-1,41} \\
& =\frac{18,91}{0,02} \\
& =94,5
\end{aligned}
$$

Setelah t di peroleh, selanjutnya dikonsultasikan dengan tabel $\mathrm{t}$ taraf signifikasi $5 \%$ maupun $1 \%$ dan dengan $\mathrm{dk}$ 62 , dari $\mathrm{dk}=62$ diperoleh taraf signifikasi $5 \%=2,00$ dan taraf signifikasi $1 \%=2,65$, karena $t_{0}$ yang diperoleh lebih besar dari $t_{\text {tabel }}$ yaitu 94,5 > 2,00 makan hipotesis nihil $\left(\mathrm{H}_{0}\right)$ di tolak dan hipotesis alternatif $\left(\mathrm{H}_{\mathrm{a}}\right)$ diterima.

Maka pada taraf signifikasi 5\% dk 62, t hitung > t tabel, yaitu 94,5 > 2,00 maka hipotesis nihil tidak ada pengaruh yang signifikan di tolak dan hipotesis alternatif yaitu ada pengaruh yang signifikan penggunaan metode kontekstual terhadap kemampuan menulis puisi melalui aliran idealisme siswa kelas X SMK Tamansiswa Kisaran Tahun Pelajaran 2016/2017 diterima. Hal ini berarti ada pengaruh yang signifikan pengruh metode Think Talk Write terhadap kemampuan menulis puisi melalui aliran ekspresionisme siswa kelas X SMK N 1 Pulau Rakyat

\section{Metode Penelitian}

dapat diketahui bahwa nilai rata- rata hasil belajar kemampuan menulis puisi melalui aliran ekspersionisme pada siswa dengan menggunakan metode Think Talk Write Ialah 86,87 dari jumlah siswa sebanyak 32 orang.

\section{Hasil dan Pembahasan}

Nilai rata- rata kemampuan menulis puisi melalui aliran ekspersionisme siswa kelas X SMK Tamansiswa Kisaran Tahun Pelajaran 2016/ 2017 sebelum menggunakan metode Think Talk Write yakni pada kelas kontrol di peroleh nilai rata-rata 67,96, sedangkan untuk kelas eksperimen diperoleh rata-rata 86,87 ini identifikasi kecenderungan masuk dalam dua kategori, yaitu kategori tinggi sebanyak 
16 orang atau 50\%, kategori cukup sebanyak 16 orang atau 50\%. Identifikasi nilai postes di atas termasuk normal dan termasuk dalam kategori wajar karena kategori yang paling banyak adalah kategori tinggi. Uji yang digunakan untuk uji normalitas nilai pretes ialah kritis melalui uji Liliefors, diperoleh $\mathrm{L}$ hitung 0,3795 dengan menggunakan $a=0,05$ dan $\mathrm{N}=32$, . Data dimasukkan dalam dua kategori, yaitu kategori sangat tinggi sebanyak 23 orang 71,875\%, kategori tinggi 9 orang atau 28,125\%. Indentifikasi nilai postes di atas termasuk normal dan termasuk dalam kategori wajar karena kategori yang paling banyak adalah kategori tinngi. Uji normalitas nilai postes dengan uji Liliefors diperoleh $\mathrm{L}_{\mathrm{hitung}}=$ 0,4226, dengan menggunakan $a$ 0,05 dan $\mathrm{N}$ = 32 maka nilai kritis melalui uji Liliefors diperoleh $\mathrm{L}_{\text {tabel }}=0,156$. Ternyata $\mathrm{L}_{\text {hitung }}>$ $\mathrm{L}_{\text {tabel }}(0,4226>0,156)$ ini membuktikan bahwa data nilai postes $(\mathrm{X})$ berdistribusi normal. Berdasarkan perhitungan di atas diperoleh $\mathrm{X}^{2}$ (chi kuadrat) hitung sebesar 0,71. Harga $X^{2}$ tabel pada taraf kepercayaan 95\% dengan $\mathrm{dk} 62$ adalah 90,50. Ternyata $X^{2}$ hitung $<X^{2}$ tabel yaitu $0,4226<0.156$. Hal ini membuktikan bahwa varians populasi adalah homogen. Maka nilai kritis melalui uji Liliefors diperoleh $\mathrm{L}_{\text {tabel }}=0,156$. Ternyata $\mathrm{L}_{\text {hitung }}>$ $\mathrm{L}_{\text {tabel }}$ yaitu 0,3795 > 0,156 ini membuktikan bahwa data nilai pretes berdistribusi normal.

Hasil diatas telah menunjukkan bahwa metode Think Talk Write memiliki kemampuan menulis puisi melalui aliran ekspersionisme X SMK Tamansiswa Kisaran Tahun Pelajaran 2016/2017. Hal ini disebabkan bahwa metode Think Talk Write lebih maksimal hasilnya karena siswa akan terlatih dalam menulis puisi melalui aliran ekspersionisme siswa kelas X SMK Tamansiswa KIsaran Tahun Pelajaran 2016/ 2017. Melalui metode Think Talk Write (TTW) ini hasil yang diperoleh siswa lebih baik dibandingkan dengan metode lain.

\section{Simpulan}

Berdasarkan penelitian yang telah dilakukan maka peneliti dapat menyimpulkan sebagai berikut:

1. Pembelajaran bahasa indonesia sebelum menggunakan metode Think Talk Write (TTW), ternyata siswa belum mampu menulis puisi dengan baik sehingga siswa masih memperoleh nilai rata-rata 67,96 berada pada nilai taraf cukup/sedang.

Vol.3 No.1 Januari - Juni 2018/ 29 
2. Pembelajaran bahasa indonesia sesudah menggunakan metode Think Talk Write (TTW), ternyata siswa sudah mampu menulis puisi dengan baik sehingga siswa memperoleh nilai rata-rata 86,87 berada pada nilai taraf baik.

3. Ada pengaruh yang signifikan metode Think Talk Write terhadap terhadap kemampuan menulis puisi melalui aliran ekspersionisme Tahun Pelajaran 2016/2017, yaitu $t$ hitung $>t_{\text {tabel, }}$ yakni $94,5>2,00$, maka hipotesis alternatif ( $\mathrm{Ha}$ ) yaitu terdapat pengaruh yang signifikan metode Think Talk Write terhadap kemampuan menulis puisi mellalui aliran ekspersionisme Tahun Pelajaran 2016/ 2017. Uji normalitas nilai postes dengan uji Liliefors diperoleh $\mathrm{L}_{\text {hitung }}$ $=0,3795$, dengan menggunakan a 0,05 dan $\mathrm{N}=32$ maka nilai kritis melalui uji Liliefors diperoleh $\mathrm{L}_{\text {tabel }}=0,156$. Ternyata $\mathrm{L}_{\text {hitung }}>\mathrm{L}_{\text {tabel }}(0,3795>0,156)$ ini membuktikan bahwa data nilai postes (X) berdistribusi normal. Uji yang digunakan untuk uji normalitas nilai postes ialah nilai kritis melalui uji Liliefors, diperoleh $\mathrm{L}_{\mathrm{hitung}}$ 0,4226 dengan menggunakan $a=0,05$ dan $\mathrm{N}=32$ maka nilai kritis melalui uji Liliefors diperoleh $\mathrm{L}_{\text {tabel }}=0,156$. Ternyata $\mathrm{L}_{\text {hitung }}>\mathrm{L}_{\text {tabel }}$ yaitu $0,4226>0,156$ ini membuktikan bahwa data nilai postes berdistribusi normal. Berdasarkan perhitungan diatas diperoleh $\mathrm{X}^{2}$ (chi kuadrat ) hitung besar 0,71. Harga $X^{2}$ tabel pada taraf kepercayaan 95\% dengan dk 62 adalah 90,50. Ternyata $\mathrm{X}^{2}$ hitung $<\mathrm{X}_{\text {tabel }}^{2}$ yaitu $0,71<90,50$. Hal ini membuktikan bahwa varians populasi adalah homogen. Setelah $\mathrm{t}$ diperoleh, selanjutnya dikonselutasikan denagn tabel t pada taraf signifikan $5 \%$ maupun $1 \%$ dan dengan $\mathrm{dk}$ 62. Pada tabel $\mathrm{t}$ dengan $\mathrm{dk}=62$ diperoleh taraf signifikan $5 \%=2,00$ dan taraf signifikan $1 \%=2,65$, karena to yang diperoleh lebih besar dari $t_{t}$ yaitu 94,5 > 2,00. Maka hipotesis nihil (Ho) ditolak dan hipotesis alternatif (Ha) diterima.

\section{DAFTAR RUJUKAN}

Aminudin. 2004. Kemampuan Menulis Puisi. Jakarta: Grasindo.

Ansari dan Yamin. 2012. Strategi Pembelajaran. Jakarta: Rajaali Pers.

Arikunto. 2002. Hipotesis Penelitian. Jakarta: Rawamangun.

Arikunto. 2005. Teori - Teori Pembelajaran. Jakarta: Rawamangun.

Arikunto, S. 2011. Dasar-Dasar Evaluasi Pendidikan. Jakarta: BumiAksara.

Balai Pustaka. 2005. Kamus Besar Berbahasa Indonesia. Jakarta: Departemen Pendidikan Nasional.

Vol.3 No.1 Januari - Juni 2018/ 30 
Dimyanti, dan Mudjiono. 2002. Belajar dan pembelajaran. Jakarta: Rienaka Cipta.

Hamalik. 2008. Kemampuan Berfikir. Jakarta: Grafiti Utama.

Huinker dan Laughlin. 1996. Model Pembelajaran. Jakarta: Rawamangun.

Istarani. 2011. 58 Model Pembelajaran Inovatif. Medan : Media Persada

Kasmina. Toali.Suhendra. Rianto, A. Susanti, A. Lisbintarti,D. 2011.matematika program keahlian teknologi, kesehatan, dan pertanian, SMK kelas XI. Jakarta: Erlangga

Komaidi dan Sopandi. 2010. Langkah Langkah Menulis Puisi. Jakarta: Balai Pustaka.

Laughlin dan Arenawa. 2008. Kerangka Konseptual. Jakarta: Kencana.

Martinis, Yamin. 2008. Mendesain Model Pembelajaran Inovatif. Jakarta: Rajawali Pers.

Mira. 2010. Kemampuan Menulis Puisi. Jakarta: Grafiti Utama.

Nurmaini. 2011. Langkah - Lngkah Think Talk Write. Jakarta: Bumi Aksar.

Ramadan, Tarmizi. 2009. Strategi belajar kuat berdua (the power of two ) dalam pembelajaran matematika (http://tarmizi.wordprees.Com/2009/0 2/09/ strategi-belajar-kekuatanberdua-the-fower-of-two-dalampembelajaran-matematika/), Diakses 28 oktober 2015.
Soleha T.W, dkk. 208. Pendidikan Bahasa Indonesia di SD. Jakarta: Universitas Terbuka.

St Y. Slamet. 2008. Dasar - dasar Pembelajaran Bahasa dan Sastra Indonesia di Sekolah Dasar. Surakarta: UNS Pers.

Sudjana. 2001. Metode Stilistika. Bandung: Trasito.

Sukardi. 2003. Metodologi Penelitian Pendidikan dan Kompetensi Praktiknya. Jakarta: PT Bumi Aksara.

Sugiyono. 2008. Metode Penelitian Pendidikan. Bandung: Alfabeta.

Sugiyono. 2010. Metode Penelitian Pendidikan. Bandung: Alfabeta

Suprapto. 1993. Ketatabahasaan dan Kesusastraan. Bandung: Angkasa Jaya.

Sudjana. 2005. Metode Statistik. Bandung: Tarsito.

Syah, Muhibbin. 2010. Psikologi pendidikan.Bandung:PT Remaja Rosdakarya

Tarigan, Henry Guntur. 1996. Keterampilan Menulis dan Berbahasa. Bandung: Angkasa Jaya.

Trianto. 2011. Mendesain model pembelajaran inovatif-progresif. Jakarta:Kencana prenada media group.

Waluyo, Herman J. 1991. Teori dan Apresiasi Puisi. Jakarta: Erlangga. 
Waluyo, Herman J. 2005. Teori dan Apresiasi Puisi. Jakarta: Erlangga.

Waluyo , Herman. 2005. Apresiasi Puisi. Jakarta: PT Gramedia Pustaka Umum.

Widowati. 2007. Teori dan Apresiasi Puisi. Jakarta: Balai Pustaka.
Wahyuni, Sri \& Dewi, R.S. 2014. Meningkatkan hasil belajar matematika melalui model pembelajaran the power of two dengan bantuan maple. Jurnal mathematics paedagogic, V(1): 18 
